\title{
ДОСЛІДЖЕННЯ СТЕРОЇДНИХ СПОЛУК ГОРЛЯНКИ ПОВЗУЧОЇ (AJUGA REPTANS L.) TPABИ
}

Вступ. На даний час актуальним є вивчення рослин, які широко розповсюджені не тільки в Україні, але й на всій земній кулі. До таких рослин належить горлянка повзуча. Відомо, що в народній медицині їі застосовують при лікуванні запальних захворювань шлунково-кишкового тракту. Стероїди належать до класу біологічно активних сполук, що проявляють протизапальну дію. У літературних джерелах немає даних щодо вмісту стероїдів у горлянки повзучої траві. Тому перспективним є вивчення цієї групи сполук.

Мета дослідження - провести дослідження з ідентифрікації і визначення кількісного та якісного вмісту стероїдних сполук у горлянки повзучої (Ajuga reptans L.) траві методом газової хроматографрії/мас-спектрометрії.

Meтоди дослідження. Об'єктом дослідження була горлянки повзучої (Ajuga reptans L.) mpaва, заготовлена в період цвітіння у с. Гута Богородчанського району в 2017-2018 рр. Методом газової хромато-мас-спектрометрії досліджено вміст стероїдних сполук у горлянки повзучої траві. Дослідження проводили на хроматографрі Agilent Technologies 6890 із мас-спектрометричним детектором 5973 з капілярною колонкою НP-5 ms (діаметром 0,25 мм, довжиною 30 м). Отримані дані фріксували за допомогою рисунків і таблиць.

Результати й обговоренння. Дані дослідження свідчать про наявність 54 речовин, з яких ідентифріковано 9 сполук: стигмастерол; прегна-5,17-дієн-3-ол; ергостерол; 3ß-стеарилокси-ерс-12-ен; стигмаста5,22-дієн-3-ол, ацетат; $\beta$-ситостерол; олеан-12-ен; 3ß-метокси-5-холестен; сліди холестеролу. Встановлено, що найбільшу концентрацію має стигмастерол, вміст якого становить 1546,20 мг/кг сировини, або 44,28 \% від усіх стероїдів цього дослідження. Виявлено значний вміст прегна-5,17-дієн-3-олу 843,91 мг/к2, або 24,17 \% від усіх стероїдів горлянки повзучої. Загальний вміст стероїдів у траві цієї рослини становить 3491,96 мг/ке.

Висновки. Методом газової хроматографрії/мас-спектрометрії визначено якісний склад та кількісний вміст стероїдів у горлянки повзучої траві. Аналіз отриманих результатів показує, що стероїдний комплекс трави рослини представлений 54 стероїдами, 9 з яких було ідентифріковано та встановлено їх кількісний вміст. Ці дані буде враховано під час подальшого одержання фрітозасобів на основі горлянки повзучої трави, а також як параметри стандартизації сировини.

КЛЮчОВІ СЛОВА: горлянка повзуча (Ajuga reptans L.); газова хроматографія; мас-спектрометрія; стероїдні сполуки.

ВСТУП. Фітостероли (рослинні стероли) є великим класом рослинних речовин, структурно надзвичайно близьких до тваринного продукту холестеролу (рис. 1). Фітостероли - натуральні компоненти мембран клітин рослин [1, 2]. Їх було відкрито в 1922 р. [3]. Найважливішими фрітостеролами є $\beta$-ситостерол, кампестерол, стигмастерол [4].

Завдяки схожості структури фрітостеролів та холестеролу, вони легко з'єднуються і блокують специфрічні рецептори, що призводить до зменшення зв'язування та абсорбції холестеролу і виведення його з організму [5]. За деякими да(c) С. В. Малюванчук, А. Р. Грицик, 2019. ними, при прийманні рослинних стеролів концентрація холестеролу в людському організмі знижується більш ніж на $15 \%$. Таким чином, потрапляючи в шлунково-кишковий тракт людини, фрітостероли перешкоджають засвоєнню екзогенного холестеролу, що надійшов з їжею, та ендогенного холестеролу, який потрапив у кишечник із жовчю. Тому при прийманні фрітостеролів знижується концентрація в крові загального холестеролу і ліпопротеїнів малої щільності, а регулярне споживання їжі, багатої на фрітостероли, може припинити розвиток атеросклеротичного процесу [6]. 
<smiles>CCC(CCC(C)C1CCC2C1CCC1C2CC=C2CC(O)CCC21C)C(C)C</smiles>

A<smiles>CC(C)CCCC(C)C1CCC2C1CCC1C2CC=C2CC(O)CCC21C</smiles>

Б

Рис. 1. Структурні фрормули фрітостеролу (А) і холестеролу (Б).

Численні клінічні дослідження, які проводили протягом 45 років у різних країнах, підтвердили безпеку фітостеролів. Стероїдні сполуки проявляють протизапальну та протиракову дію [7].

Зокрема, горлянки Лаксмана трава входить до збору М. Н. Здренко, який застосовують при багатьох патологічних процесах, що перебігають в організмі, та для лікування онкологічних захворювань. В Україні горлянка повзуча не є фармакопейною рослиною. Тенденції розвитку вітчизняного ринку лікарської рослинної сировини свідчать про перспективність фрітохімічного вивчення горлянки повзучої трави, тому доцільно дослідити вміст стероїдних сполук цієї рослини.

Мета дослідження - провести дослідження з ідентифрікації і визначення кількісного та якісного вмісту стероїдних сполук у горлянки повзучої (Ajuga reptans L.) траві методом газової хроматограсрії/мас-спектрометрії.

МЕТОДИ ДОСЛІДЖЕННЯ. Об'єкТом дослідження була горлянки повзучої (Ajuga reptans L.) трава, заготовлена в період цвітіння у с. Гута Богородчанського району в 2017-2018рр. Досліджувану сировину попередньо обробляли хлороформом в апараті Соксклета.

0,05 г подрібненої сировини (точна наважка) вміщували у віалу об'ємом 2 мл, як внутрішній стандарт додаючи тридекан з розрахунку 50 мкг на наважку, а як розчинник - 6 мл метиленхлориду [7]. Протягом 3 год віали витримували в ультразвуковому екстракторі. До віали об'ємом 2 мл переносили отриману витяжку та концентрували, продуваючи потоком особливо чистого нітрогену (швидкість потоку - 100 мл/хв) до залишкового об'єму витяжки 10 мкл. Дослідження проводили на хроматограсрі Agilent Technologies 6890 із мас-спектрометричним детектором 5973 3 капілярною колонкою HP-5 ms (діаметром 0,25 мм, довжиною 30 м). Швидкість газу-носія (гелію) становила 1,0 мл/хв, температура нагрівача проби - $350{ }^{\circ} \mathrm{C}$, температуру термостата програмували від 150 до $300{ }^{\circ} \mathrm{C}$ зі швидкістю 7 град/хв. Використовуючи бібліотеку мас-спектрів у поєднанні з програмами для ідентифрікації AMDIS тa NIST, ідентифрікували компоненти [8-13].

Кількісний вміст стероїдів (X, мг/кг) визначали методом внутрішніх стандартів за фрормулою:

$$
\mathrm{X}=\frac{\Pi_{1} \times 50}{\Pi_{2} \times \mathrm{m}},
$$

де $\Pi_{1}$ - площа піка речовини, яку вивчали;

50 - маса внутрішнього стандарту, який вводили в зразок, мкг;

$\Pi_{2}$ - площа піка стандарту;

m - наважка сировини, г.

РЕЗУЛЬТАТИ Й ОБГОВОРЕННЯ. ХРОМаТОграму стероїдних сполук горлянки повзучої трави наведено на рисунку 2.

Якісний та кількісний вміст стероїдних сполук у горлянки повзучої траві наведено в таблиці.

Таблиця - Ідентифріковані стероїдні сполуки горлянки повзучої трави

\begin{tabular}{|c|c|c|c|}
\hline \multirow{2}{*}{ Компонент } & \multirow{2}{*}{ Час утримання, хв } & \multicolumn{2}{|c|}{ Вміст } \\
\hline & & $\%$ & $\mathrm{M \Gamma} / \mathrm{K} \Gamma$ \\
\hline Холестерол & 20,78 & \multicolumn{2}{|c|}{ сліди } \\
\hline Ергостерол & 21,61 & 8,07 & 281,69 \\
\hline Ізохолестерол & 21,77 & 2,12 & 74,10 \\
\hline Прегна-5,17-дієн-3-ол & 22,06 & 24,17 & 843,91 \\
\hline Стигмастерол & 22,46 & 44,28 & 1546,20 \\
\hline Олеан-12-ен & 22,66 & 3,81 & 133,07 \\
\hline 3ß-стеарилокси-ерс-12-ен & 23,07 & 7,81 & 272,86 \\
\hline Стигмаста-5,22-дієн-3-ол, ацетат & 24,31 & 5,61 & 196,06 \\
\hline Усього & & & 3491,96 \\
\hline
\end{tabular}




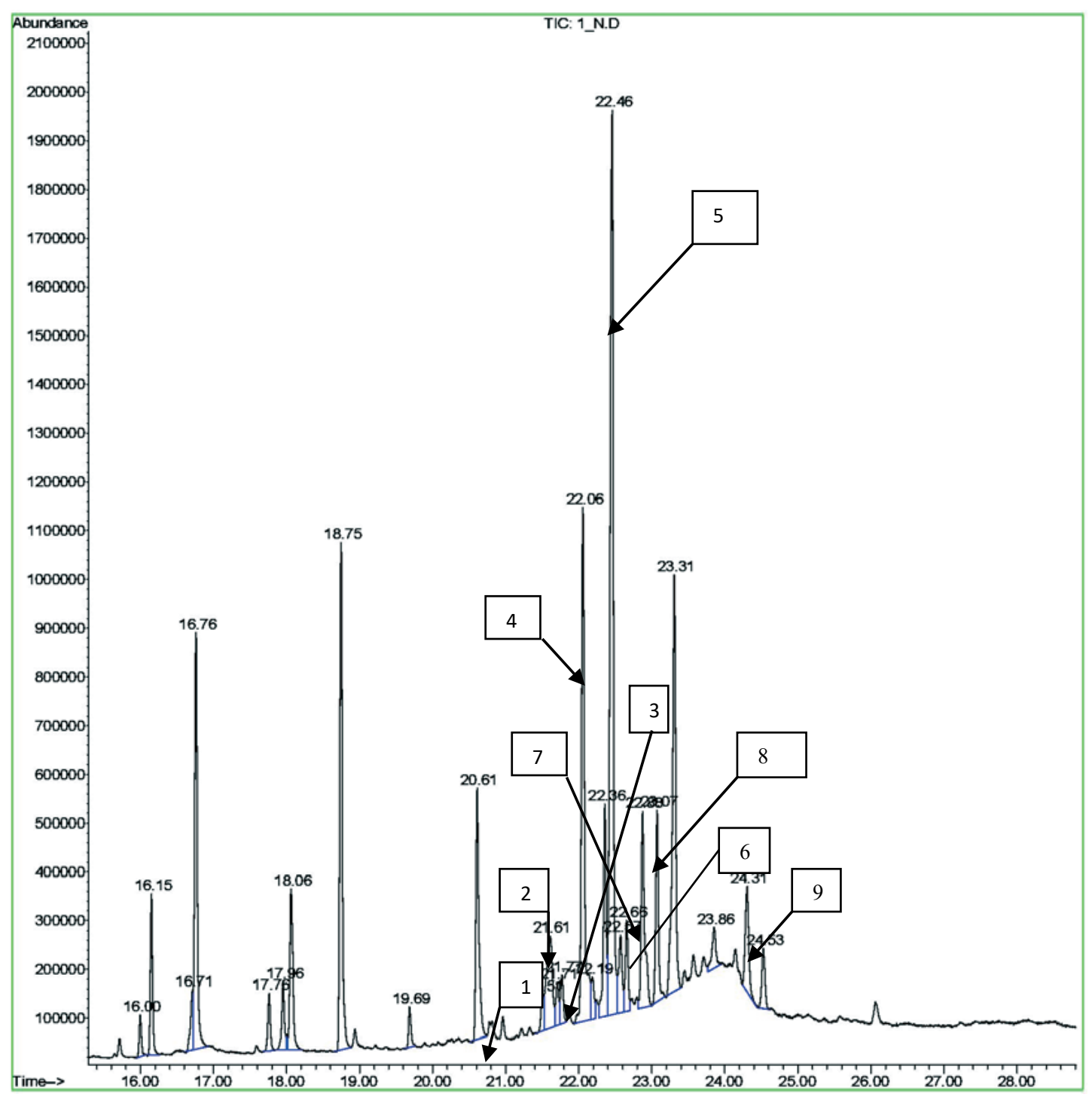

Рис. 2. Хроматограсрічний просріль стероїдів горлянки повзучої трави: 1 -холестерол; 2 - ергостерол; 3 - ізохолестерол; 4 - прегна-5,17-дієн-3-ол; 5 - стигмастерол; 6 - $\beta$-ситостерол; 7 - олеан-12-ен; 8 - 3ß-стеарилокси-ерс-12-ен; 9 стигмаста-5,22-дієн-3-ол, ацетат.

ВИСНОВКИ. 1. Методом газової хроматографії/мас-спектрометрії визначено якісний склад та кількісний вміст стероїдів у горлянки повзучої траві.

2. Стероїдний комплекс горлянки повзучої трави представлений такими стероїдами, як: стигмастерол; прегна-5,17-дієн-3-ол; ергостерол; 3ß-стеарилокси-ерс-12-ен; стигмаста-5,22-дієн3-ол, ацетат; $\beta$-ситостерол; олеан-12-ен; $3 \beta$-метокси-5-холестен; сліди холестеролу. Встановлено, що найбільшу концентрацію має стиг- мастерол, вміст якого становить 1546,20 мг/кг сировини, або 44,28 \% від усіх стероїдів цього дослідження. Виявлено значний вміст прегна5,17-дієн-3-олу - 843,91 мг/кг, або 24,17 \% від усіх стероїдів горлянки повзучої. Загальний вміст стероїдів у траві цієї рослини становить 3491,96 мг/кг.

3. Отримані дані буде враховано під час подальшого одержання фрітозасобів на основі горлянки повзучої трави, а також як параметри стандартизації сировини. 


\section{СПИСОК ЛІТЕРАТУРИ}

1. Ситопростат [Електронний ресурс] / Компанія “Таблетки. Ua". - Режим доступу : http: pharmplanet. com.ua/ua/produkty-sitoprostat.

2. Холестерин та його ефріри [Електронний ресурс]. - Режим доступу : http://www.terra-aromatica.ru/ lipidy-rogovogo-sloya-holesterin-ego-efiry-alternativnoeispolzovanie-fitosterolov-i-35.html.

3. Бета-ситостерин - роль у здоров'ї людини, food and health [Електронний ресурс]. - Режим доступу : http://jak.bono.odessa.ua/articles/beta-sitosterin-rol-uzdorov-i-ljudini-food-and.php.

4. Ericson-Neilsen W. Steroids: pharmacology, complications and practice delivery issues / J. EricsonNeilsen // Ochsner J. - 2014. - 14. - P. 203-207.

5. Pharmacologically screened aphrodisiac plant $-\mathrm{a}$ review of currentscientific literature / D. K. Patel, R. Kumar, S. K. Prasad, S. Hemalatha // Asian Pacific Journal of Tropical Biomedicine. - 2011. - No. 1. - P. 131-138.

6. Dose effects of dietary phytosterols on cholesterol metabolism: a controlled feeding study / S. B. Racette, X. Lin, M. Lefevre [et al.] // Jr. Am. J. Clin. Nutr. - 2010. 91 (1). - P. 32-38.

7. Гур'єва І. Г. Вивчення стероїдних сполук та коренів тифону / І. Г. Гур'єва // Фітотерапія. - 2014. № 1. - С. 71-73.

8. Стероидные соединения сырья Verbascum thapsus L. / A. А. Волошина, В. С. Кисличенко,
И. А. Журавель, Н. Е. Бурда // Рецепт. - 2013. № 2 (88). - C. 95-99.

9. Тимофеєєва С. В. Вивчення стероїдних сполук у сировині канни садової / С. В. Тимофрєєва, О. А. Кисличенко, I. О. Журавель // ScienceRise. Pharmaceutical Science. - 2017. - № 2 (6). - C. 38-41.

10. Вивчення стероїдних сполук у сировині моркви посівної сортів "Яскрава" та "Нантська Харківська" / Д.-М. В. Пазюк, І. О. Журавель, О. А. Кисличенко, Н. Є. Бурда // Фітотерапія. Часопис. - 2017. - № 1. C. 31-33.

11. Бурда Н. Є. Вивчення стероїдних сполук грибів шиїтаке, рейши та кордіцепсу / Н. Є. Бурда // Фітотерапія. Часопис. - 2013. - № 4. - С. 67-69.

12. Бурда Н. Є. Вивчення стероїдних сполук у сировині півонії лікарської сортів "Alba plena" та "Rosea plena" / Н. Є. Бурда // Фітотерапія. Часопис. - 2014. № 1. - C. 67-70.

13. Kyslychenko O. A. Gas chromatography with mass-spectrometric detection of the essential oils from Achillea carpatica Blocki ex Dubovik and Echinacea pallida (nutt.) Nutt / O. A. Kyslychenko, Ya. V. Dyakonova, V. A. Khanin [et al.] // Abstracts 6th International Symposium on Chromatography of Natural Products (ISCNP). Lublin; 2008. - 136 p.

Verbascum thapsus [Steroid compounds of Verbascum thapsus L.]. Retsept - Recipe, 2 (88), 95-99 [in Russian].

9. Tymofieieva, S.V., Kyslychenko, A.A., \& Zhuravel, I.O. (2017). Vyvchennia steroidnykh spoluk u syrovyni KANNY SADOVOI [Study of steroid compounds in raw CANNY GARDEN]. Scientific Journal "ScienceRise: Pharmaceutical Science", 2 (6), 38-41 [in Ukrainian].

10. Paziuk, D.-M. V., Zhuravel, I.O., Kyslychenko, A.A., \& Bourda, N.E. (2017). Vyvchennia steroidnykh spoluk u syrovyni morkvy posivnoi sortiv "Yaskrava" ta "Nantska Kharkivska [Study of steroid compounds in the raw carrots of the seedlings "Yaskrava" and "Nantska Kharkivska"]. Fitoterapiia. Chasopys - Phytotherapy, Journal, 1, 31-33 [in Ukrainian].

11. Burda, N.Ye. (2013). Vyvchennia steroidnykh spoluk hrybiv shyitake, reyshy ta korditsepsu [Study of the steroid compounds of mushroom shiites, Reichs and Cordyceps]. Fitoterapiia. Chasopys - Phytotherapy, Journal, 4, 67-69 [in Ukrainian].

12. Burda, N.Ye. (2014). Vyvchennia steroidnykh spoluk u syrovyni pivonii likarskoi sortiv "Alba plena" ta "Rosea plena" [Study of steroid compounds in raw pions of medicinal varieties "Alba plena" and "Rosea plena"]. Fitoterapiia. Chasopys - Phytotherapy, Journal, 1, 67-70 [in Ukrainian].

13. Kyslychenko, O.A., Dyakonova, Ya.V., \& Khanin, V.A. (2008). Gas chromatography with mass-spectrometric detection of the essential oils from Achillea carpatica Blocki ex Dubovik and Echinacea pallida (nutt.) Nutt. Abstracts 6th International Symposium on Chromatography of Natural Products (ISCNP). Lublin. 


\section{ИССЛЕДОВАНИЕ СТЕРОИДНЫХ СОЕДИНЕНИЙ ЖИВУЧКИ ПОЛЗУЧЕЙ (AJUGA REPTANS L.) TPABЫ}

\section{Резюме}

Вступление. В настоящее время актуальным является изучение растений, которые широко распространены не только в Украине, но и по всему земному шару. К таким растениям принадлежит живучка ползучая. Известно, что в народной медицине ее применяют при лечении воспалительных заболеваний желудочно-кишечного тракта. Стероиды относят к классу биологически активных соединений, которые проявляют противовоспалительное действие. В литературных источниках нет данных относительно содержания стероидов в живучки ползучей траве. Поэтому перспективным является изучение этой группы соединений.

Цель исследования - провести исследование по идентификации и определению количественного и качественного содержания стероидных соединений в живучки ползучей (Ajuga reptans L.) mpaве методом газовой хроматографии/масс-спектрометрии.

Методы исследования. Объектом исследования была живучки ползучей (Ajuga reptans L.) mpaвa, заготовленная в период цветения в с. Гута Богородчанского района в 2017-2018 г2. Методом газовой хромато-масс-спектрометрии исследовано содержание стероидных соединений в живучки ползучей траве. Исследование проводили на хроматографpe Agilent Technologies 6890 с масс-спектрометрическим детектором 5973 с капиллярной колонкой HP-5 ms (диаметром 0,25 мм, длиной 30 м). Полученные данные фиксировали с помощью рисунков и таблиц.

Результаты и обсуждение. Данные исследования свидетельствуют о наличии 54 веществ, из которых идентифицировано 9 соединений: стигмастерол; прегна-5,17-диен-3-ол; эргостерол; 3ß-стеарилокси-эрс-12-ен; стигмаста-5,22-диен-3-ол, ацетат; $\beta$-ситостерол; олеан-12-ен; 3ß-метокси-5-холестен; следы холестерола. Установлено, что наибольшую концентрацию имеет стигмастерол, содержание которого составляет 1546,20 мг/кг сырья, или 44,28 \% от всех стероидов этого исследования. Выявлено значительное содержание прегна-5,17-диен-3-ола - 843,91 мг/ке, или 24,17 \% от всех стероидов живучки ползучей. Общее содержание стероидов в траве этого растения составляет 3491,96 мг/кг.

Выводы. Методом газовой хроматографии/масс-спектрометрии определено качественный состав и количественное содержание стероидов в живучки ползучей траве. Анализ полученных результатов показывает, что стероидный комплекс травы растения представлен 54 стероидами, 9 из которых было идентифицировано и установлено их количественное содержание. Эти данные будут учтены во время дальнейшего получения фитопрепаратов на основе живучки ползучей травы, а также в качестве параметров стандартизации сырья.

КЛЮЧЕВЫЕ СЛОВА: живучка ползучая (Ajuga reptans L.); газовая хроматография; массспектрометрия; стероидные соединения.

S. V. Maliuvanchuk, A. R. Grytsyk IVANO-FRANKIVSK NATIONAL MEDICAL UNIVERSITY

\section{INVESTIGATION OF STEROID COMPOUNDS OF AJUGA REPTANS L. HERB}

\section{Summary}

Introduction. Nowadays, the study of plants which are widespread not only in Ukraine but also throughout the globe is relevant. One of these plants is Ajuga reptans L. It is known that in folk medicine Ajuga reptans L. is used in treating of inflammatory diseases of the gastrointestinal tract. Steroids are a class of biologically active compounds that exhibit anti-inflammatory activity. Literature data do not consist any sources on the content of steroids in the Ajuga reptans $L$. herb. That is why the study of this group of compounds is promising.

The aim of the study - to conduct a study on the identification and determination of the quantitative and qualitative content of steroid compounds of Ajuga reptans L. herb. (Ajuga reptans L.) using gas chromatography/ mass spectrometry

Research Methods. The object of the study was the herb of Ajuga reptans L. harvested during the flowering period in the village Huta of Bohorodchany district in 2017-2018 years. The method of gas chromatography-mass 
spectrometry has been used to study the content of steroid compounds in the Ajuga reptans L.herb. The research was carried out on the Agilent Technologies 6890 chromatograph with a mass spectrometric detector 5973 and the capillary column HP-5 ms (0.25 mm in diameter, $30 \mathrm{~m}$ in length). The obtained data were recorded using figures and tables.

Results and Discussion. These studies indicate the presence of 54 substances, 9 of which have been identified: stigmasterol; pregna-5,17-dien-3-ol; ergosterol; 3ß-stearyloxy-ers-12-ene; stigmasta-5,22-dien-3-ol, acetate;

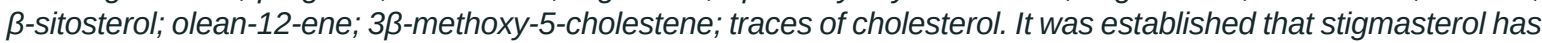
the highest concentration. Its content is $1546.20 \mathrm{mg} / \mathrm{kg}$ of raw materials or $44.28 \%$ of the content of all the identified steroids. A significant content of pregna-5,17-dien-3-ol was found - $843.91 \mathrm{mg} / \mathrm{kg}$ or $24.17 \%$ of all steroids of Ajuga reptans L. herb. The total content of steroids in the Ajuga reptans L. herb is $3491.96 \mathrm{mg} / \mathrm{kg}$.

Conclusions. The method of gas chromatography-mass spectrometry was used to determine the qualitative composition and quantitative content of steroids of Ajuga reptans $L$. herb. The analysis of the obtained results shows that the steroid complex of Ajuga reptans L. herb is represented by 54 steroids, 9 of which were identified and quantified. The obtained data will be taken into account for further production of the herbal drugs based on Ajuga reptans $L$. herb as well as the standardization parameters of the raw material.

KEY WORDS: Ajuga reptans L.; gas chromatography; mass spectrometry; steroid compounds.

Отримано 10.04.19

Адреса для листування: С. В. Малюванчук, Івано-Франківський національний медичний університет, вул. Галицька, 2, Івано-Франківськ, 76018, Україна, е-mail: sv_malyv@ukr.net. 